\title{
A contribution to the study of hydrophobicity (lipophilicity) of bile acids with an emphasis on oxo derivatives of $5 \beta$-cholanoic acid
}

\author{
Mihalj Poša ${ }^{1}$, Milena Rašeta ${ }^{2}$, Ksenija Kuhajda ${ }^{2}$ \\ ${ }^{1}$ Department of Pharmacy, Faculty of Medicine, University of Novi Sad, Novi Sad, Serbia \\ ${ }^{2}$ Department of Chemistry, Faculty of Sciences, University of Novi Sad, Novi Sad, Serbia
}

\begin{abstract}
Due to their promotory action on the transport of some drugs through various membranes (lipophilic barriers), oxo derivatives of bile acids have recently been increasingly used in biopharmacy. These compounds also exhibit a lower membranolytic (toxic) activity than their hydroxy analogues. Because of that, it is of special importance to find out the descriptors that would adequately describe the structure of bile acids and their biological activity and be used to model the quantitative structure-activity relationship. In view of this, the present work is concerned with the application of the chromatographic parameter $R_{\mathrm{M}}{ }^{0}$ obtained by normal-phase thin-layer chromatography in the solvent system toluene-butanol and silica gel as stationary phase to describe the lipophilicity of bile acids. Also, the work introduces a new molecular descriptor (ND) that reflects both 2D and 3D topological characteristics of the molecule. Between the retention constant, $R_{\mathrm{M}}{ }^{0}$ and the descriptor ND there is a good correlation, and both $R_{\mathrm{M}}{ }^{0}$, and ND describe sufficiently well the structural (conformational) changes that arise in the process of oxidation of the $\mathrm{OH}$ group of the steroid skeleton to an oxo group. On the other hand, the in silico descriptors of lipophilicity, $\log P$ (atomic-based prediction) and $C \log P$ (fragment-based prediction) predict the hydrophobicity of bile acid oxo derivatives with a certain error.
\end{abstract}

Keywords: Bile acid oxo derivatives $\bullet$ Hydrophobicity (lipophilicity) $\bullet$ Retention constant $-R_{\mathrm{M}}{ }^{0}$

SCIENTIFIC PAPER

UDC 547.93:544.722.123/.133

Hem. Ind. 65 (2) 115-121 (2011)

doi: 10.2298/HEMIND100924071P

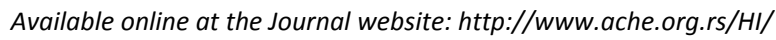

Bile acids are amphiphilic compounds with a steroid skeleton in their molecules (surface active substances) $[1,2]$. Namely, the $\beta$ side of the steroid nucleus is the more hydrophobic (lipophilic) surface of the molecule, whereas the $\alpha$ side is the less hydrophobic (i.e., hydrophilic) surface [3]. The hydrophobicity, i.e., lipophilicity, of bile acid molecules plays an important role in their interaction with the receptors, enzymes, ionic channels, cell membranes, etc. [4]. Namely, it is known that the hydrophilic-hydrophobic balance ( $\mathrm{HHB}$ ) of bile acids determines their ability to bind to the large conductance $\mathrm{Ca}^{2+}$-activated $\mathrm{K}^{+}\left(\mathrm{BK}_{\mathrm{Ca}}\right)$ channel, which results in the relaxation of the endothelial smooth muscles [5]. Also, the HHB indicates the promotory properties of bile acids in the transport of polar drugs through biological membranes [6,7]. It is necessary to point out that this property determines the membrane toxicity of bile acids [8].

Lipophilicity can be expressed in terms of many different descriptors $\left(\log P, \pi, f, \log k_{\mathrm{w}}, R_{\mathrm{M}}, R_{\mathrm{M}}{ }^{0}\right)$ obtained experimentally or calculated. The most frequently used experimental parameters are retention constants, $R_{\mathrm{M}}{ }^{0}$

Correspondence: M. Poša, Department of Pharmacy, Faculty of Medicine, University of Novi Sad, Hajduk Veljkova 3, 21000 Novi Sad, Serbia.

E-mail: mihaljp@uns.ac.rs

Paper received: 24 September, 2010

Paper accepted: 23 November, 2010
(RP TLC) and $\log k_{\mathrm{w}}$ (RP HPLC) $[9,10]$. It is accepted that retention constants $\left(R_{\mathrm{M}}{ }^{0}\right.$ and $\left.\log k_{\mathrm{w}}\right)$ of lipophilicity are more precise and reproducible than those determined by traditional "shake-flask" methods [11,12]. Many QSAR (quantitative structure activity relationship) models involve the lipophilicity descriptors ( $\log P$ or chromatograpic parameters). Hence, in order for the obtained QSAR model to have adequate predictivity it is necessary that these descriptors describe with great fidelity structural differences between the molecules encompassed by the given model [13].

The aim of this work was to compare the experimental retention constants (normal-phase thin-layer chromatography, NP TLC) and molecular lipophilicity descriptors, i.e., in silico descriptors of partition coefficients $-\log P$ (atom-based prediction) and Clog $P$ (fragment-based prediction) - that are obtained by conventional software packages ChemDraw, Alchemica, etc. $[14,15]$. In other words, the objective is to check whether the experimental lipophilicity parameters or in silico lipophilicity parameters describe more adequately the structural characteristics of bile acids. Also, the work introduces a new descriptor based on the molecular graph and conformational analysis of the steroid skeleton as a lipophilicity descriptor. In addition to the common hydroxy derivatives, the work is concerned with oxo derivatives of the investigated bile acids (Figure 1). Namely, oxo derivatives, because of their lower 
membrane toxicity, have received an increasing application in biopharamcological investigations [16-19].

\section{EXPERIMENTAL}

\section{Synthesis of oxo derivatives of cholic, deoxycholic and chenodeoxycholic acids}

Cholic, deoxycholic and chenodeoxycholic acids (Sigma, New Zeland, 98\%) were used as the starting compounds for the synthesis of their oxo derivatives.

$3 \alpha$-Hydroxy-12-oxo-5 $\beta$-cholanoic acid (12-oxo-lithocholic acid) and $3 \alpha, 7 \alpha$-dihydroxy-12-oxo- $5 \beta$-cholanoic acid (12-oxo-chenodeoxycholic acid) were prepared according to the procedure of Miljković et al. [20], while $3 \alpha, 12 \alpha$-dihydroxy-7-oxo-5 $\beta$-cholanoic acid (7-oxo-deoxycholic acid) and $3 \alpha$-hydroxy-7-oxo- $5 \beta$-cholanoic acid (7-oxo-lithocholic) were obtained according to Tullar [21]. $3 \alpha$-Hydroxy-7,12-dioxo-5 $\beta$-cholanoic acid (7,12-dioxo-lithocholic acid) was synthesized by a selective oxidation of the $7 \alpha$-hydroxy group of $3 \alpha, 7 \alpha$-dihydroxy-12-oxo-5 $\beta$-cholanoic acid following the procedure of the same author (Tullar). The starting compound for obtaining $12 \alpha$-hydroxy-3,7-dioxo-5 $\beta$-cholanoic acid was methyl cholate, selectively oxidized in one-pot reaction according to Kuwada et al. [22] . 3,7,12-Trioxo-5 $\beta$-cholanoic acid (3,7,12-trioxo-cholanoic acid or dehydrocholic acid), 3,12-dioxo-5 $\beta$-cholanoic acid (3,12-dioxo-cholanoic acid) and 3,7-dioxo-5 $\beta$-cholanoic acid (3,7-dioxocholanoic acid) were obtained according to Fieser and Rajagopalan [23]. The purity of the synthesized com- pound was higher than $98 \%$. Hyodeoxycholic acid was bought from Sigma, New Zeland, 98\%.

\section{Determination of molecular lipophilicity by RPTLC}

The retention constant, $R_{\mathrm{M}}{ }^{0}$, was determined by NP TLC with silica gel (Merck) as stationary phase, starting from the following equation:

$R_{\mathrm{M}}=\log \left(1 / R_{\mathrm{f}}-1\right)$

where $R_{\mathrm{f}}$ represents the retention factor. The value of $R_{\mathrm{M}}$ depends linearly on the logarithm of the concentration of the organic modifier (ethanol or butanol) in the mobile phase (toluene) according to the following relation (Figure 2):

$R_{\mathrm{M}}=R_{\mathrm{M}}{ }^{0}+b \log c$

in which $R_{\mathrm{M}}{ }^{0}$ is the intercept [24]. The concentration of organic modifier (ethanol or butanol) in the mobile phase ranged from 5 to $35 \%$.

\section{Data treatment}

Pearson's correlation obtained using the program package of Statistica 8.0. The 3D models (energetically most favorable) of bile acids generated according to the MOPAC protocol (ChemBio3D Ultra 11.0) that are used to obtain the in silico $\log P$ and $C \log P$.

\section{RESULTS AND DISCUSSION}

As can be seen from Table 1, for both solvent systems, the oxo derivatives of the investigated bile acids

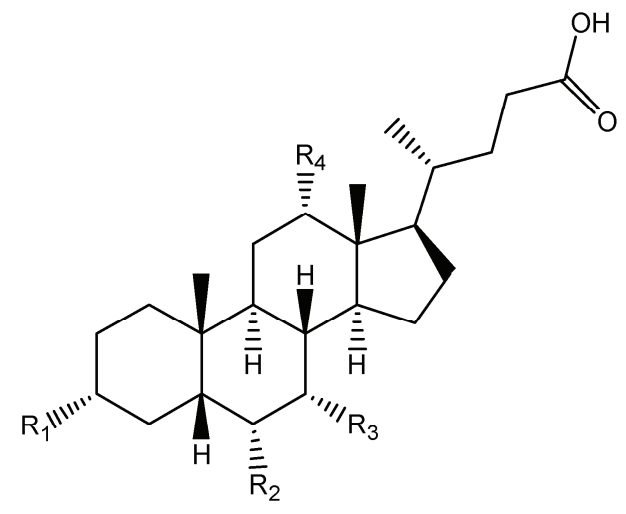

\begin{tabular}{|c|c|}
\hline $\mathbf{R}_{\mathbf{1}}=\mathbf{R}_{4}=\mathrm{OH} ; \mathbf{R}_{\mathbf{2}}=\mathbf{R}_{\mathbf{3}}=\mathrm{H}$ & $3 \alpha, 12 \alpha$-dihydroxy-5 $\beta$-cholanoic acid (deoxycholic acid); 1 \\
\hline $\mathbf{R}_{\mathbf{1}}=\mathbf{R}_{\mathbf{3}}=\mathrm{OH} ; \mathbf{R}_{\mathbf{2}}=\mathbf{R}_{\mathbf{4}}=\mathbf{H}$ & $3 \alpha, 7 \alpha$-dihydroxy- $5 \beta$-cholanoic acid (chenodeoxycholic acid); $\mathbf{2}$ \\
\hline $\mathbf{R}_{\mathbf{1}}=\mathbf{R}_{3}=\mathbf{R}_{\mathbf{4}}=\mathrm{OH} ; \mathbf{R}_{\mathbf{2}}=\mathrm{H}$ & $3 \alpha, 7 \alpha, 12 \alpha$-trihydroxy-5 $\beta$-cholanoic acid (cholic acid); 3 \\
\hline $\mathbf{R}_{1}=\mathrm{OH} ; \mathbf{R}_{4}==0 ; \mathbf{R}_{2}=\mathbf{R}_{3}=\mathbf{H}$ & $3 \alpha$-hydroxy-12-oxo-5 $\beta$-cholanoic acid (12-oxo-lithocholic acid); 4 \\
\hline $\mathbf{R}_{\mathbf{1}}=\mathbf{R}_{4}==\mathbf{0} ; \mathbf{R}_{\mathbf{2}}=\mathbf{R}_{\mathbf{3}}=\mathbf{H}$ & 3,12-dioxo-5 $\beta$-cholanoic acid (3,12-dioxo-cholanoic acid); 5 \\
\hline $\mathbf{R}_{\mathbf{1}}=\mathrm{OH} ; \mathbf{R}_{\mathbf{3}}==\mathbf{O} ; \mathbf{R}_{2}=\mathbf{R}_{4}=\mathrm{H}$ & $3 \alpha$-hydroxy-7-oxo-5 $\beta$-cholanoic acid (7-oxo-lithocholic acid); 6 \\
\hline$R_{1}=R_{3}==0 ; R_{2}=R_{4}=H$ & 3,7-dioxo-5 $\beta$-cholanoic acid (3,7-dioxo-cholanoic acid); 7 \\
\hline $\mathbf{R}_{1}=\mathbf{R}_{3}=\mathrm{OH} ; \mathbf{R}_{4}==\mathrm{O} ; \mathbf{R}_{2}=\mathrm{H}$ & $3 \alpha, 7 \alpha$-dihydoxy-12-oxo-5 $\beta$-cholanoic acid (12-oxo-chenodeoxycholic acid); 8 \\
\hline$R_{1}=R_{4}=O H ; R_{3}==O ; R_{2}=H$ & $3 \alpha, 12 \alpha$-dihydroxy-7-oxo-5 $\beta$-cholanoic acid (7-oxo-deoxycholic acid); 9 \\
\hline $\mathbf{R}_{\mathbf{1}}=\mathrm{OH} ; \mathbf{R}_{\mathbf{3}}=\mathbf{R}_{4}==\mathrm{O} ; \mathbf{R}_{\mathbf{2}}=\mathbf{H}$ & 3 $\alpha$-hydroxy-7,12-dioxo-5 $\beta$-cholanoic acid (7,12-dioxo-lithocholic acid); 10 \\
\hline $\mathbf{R}_{4}=\mathrm{OH} ; \mathbf{R}_{\mathbf{1}}=\mathbf{R}_{3}==\mathrm{O} ; \mathbf{R}_{2}=\mathrm{H}$ & $12 \alpha$-hydroxy-3,7-dioxo-5 $\beta$-cholanoic acid; 11 \\
\hline $\mathbf{R}_{1}=\mathbf{R}_{3}=\mathbf{R}_{4}==\mathbf{0} ; \mathbf{R}_{2}=\mathbf{H}$ & 3,7,12-trioxo-5 $\beta$-cholanoic acid (3,7,12-trioxo-cholanoic acid); 12 \\
\hline$R_{1}=R_{2}=O H ; R_{3}=H ; R_{4}=H$ & $3 \alpha, 6 \alpha$-dihydroxy-5 $\beta$-cholanoic acid (hyodeoxycholic acid); 13 \\
\hline
\end{tabular}

Figure 1. Structures of tested bile acids. 
have experimentally determined values of retention constant, $R_{\mathrm{M}}{ }^{0}$, that are smaller compared to those for cholic, deoxycholic and chenodeoxycholic acids. This can be explained by the fact that the substitution of the $\alpha$-oriented $\mathrm{OH}$ group with oxo groups shifts the position of the oxygen atom towards the mean plane of the steroid system (Figure 3A). When the $\mathrm{OH}$ group has either an $\alpha$-axial $(a)$ or $\alpha$-equatorial (e) orientation, the steric position of the oxygen atom in the corresponding Newman formula after the oxidation of the $\mathrm{OH}$ to oxo group is shifted by $60^{\circ}$ toward the angular methyl groups $[8,16]$. This change in the position of the oxygen atom leads to the stabilization of water molecules by hydrogen bonds (SWM) in the solvation sheath of the bile acid molecule (oxo derivative), both from the $\alpha$ and partially from the $\beta$ side of the steroid skeleton. Thus, the amount of nonstabilized water molecules (NSWM) in the solvation sheath of the investigated bile acid molecule is decreased $[25,26]$. This means that oxo derivatives of the investigated bile acids are more stabilized in water than cholic, deoxycholic and chenodeoxycholic acids. Hence, their oxo derivatives have also a lower tendency to pass to the organic phase, i.e., 1-octanol (Figure 3B), and, consequently, they have lower $\log P$ values compared to those of cholic, deoxycholic and chenodeoxycholic acids. In other words, their hydrophobicity (lipophilicity) is lowered. An analogous explanation concerning the $\log P$ is also the process of binding to the polar stationary phase in NP TLC. Namely, the more hydrophobic the bile acid, the stronger

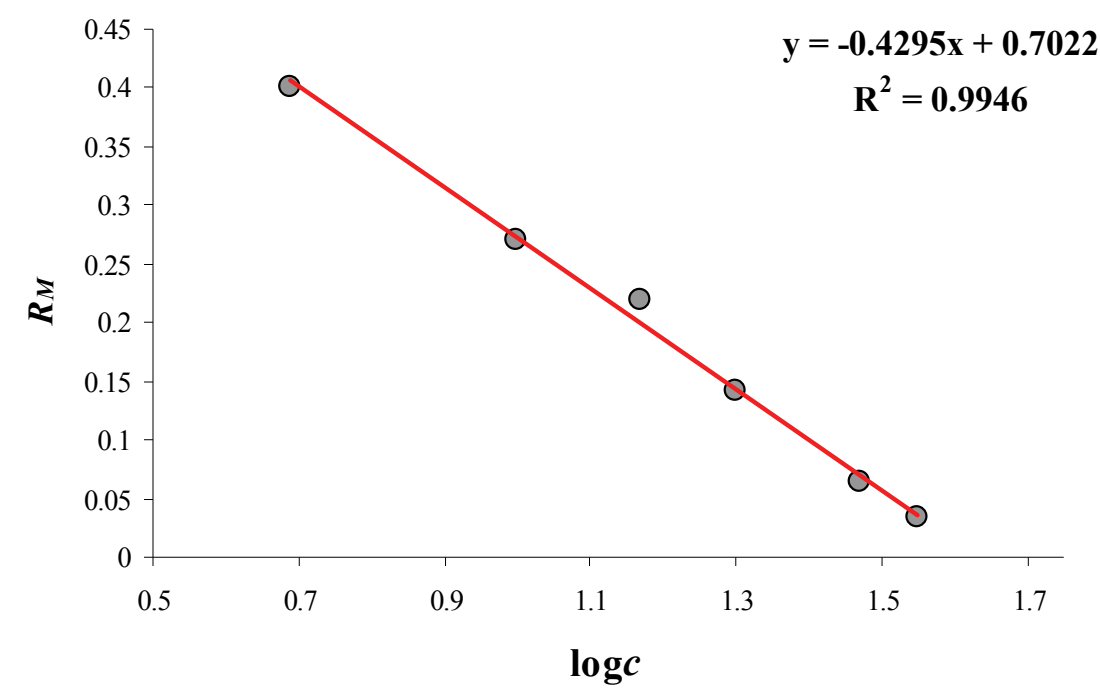

\begin{tabular}{ccccccc}
\hline$c[\%]$ & 5 & 10 & 15 & 20 & 30 & 35 \\
\hline $\boldsymbol{R}_{f}$ & 0.27 & 0.34 & 0.37 & 0.42 & 0.46 & 0.49 \\
\hline
\end{tabular}

Figure 2. Relationship between $R_{M}$ and concentration ( $\left.\log c\right)$ of modifier, ethanol (example of the 7-oxo-deoxycgolic acid, 9).

Table 1. Parameters of lipophilicity (hydrophobicity) of bile acids

\begin{tabular}{lccccc}
\hline \multirow{2}{*}{ Bile acid } & \multicolumn{3}{c}{ Calculated } & \multicolumn{3}{c}{ Experimental $R_{\mathrm{M}}{ }^{0} \pm \mathrm{sd}(n=5)$} \\
\cline { 2 - 6 } & $\log P$ & Clog $P$ & $N D$ & Toluene/ethanol & Toluene/butanol \\
\hline Deoxycholic acid (1) & 4.20 & 4.51 & 6.25 & $1.23 \pm 0.08$ & $1.46 \pm 0.07$ \\
Chenodeoxycholic acid (2) & 4.13 & 4.51 & 6.25 & $1.20 \pm 0.06$ & $1.44 \pm 0.08$ \\
Cholic acid (3) & 3.04 & 2.43 & 4.0 & $0.85 \pm 0.03$ & $1.03 \pm 0.05$ \\
12-Oxo-lithocholic acid (4) & 4.69 & 4.11 & 5.0 & $1.04 \pm 0.03$ & $1.25 \pm 0.05$ \\
3,12-Dioxo-cholanoic acid (5) & 4.84 & 3.71 & 3.75 & $0.81 \pm 0.04$ & $1.01 \pm 0.05$ \\
7-Oxo-lithocholic acid (6) & 4.45 & 4.11 & 5.0 & $1.01 \pm 0.05$ & $1.22 \pm 0.05$ \\
3,7-Dioxo-cholanoic acid (7) & 4.61 & 4.07 & 3.75 & $0.82 \pm 0.03$ & $0.97 \pm 0.04$ \\
12-Oxo-chenodeoxycholic acid (8) & 3.53 & 2.03 & 3.5 & $0.69 \pm 0.02$ & $0.87 \pm 0.03$ \\
7-Oxo-deoxycholic acid (9) & 3.36 & 2.03 & 3.5 & $0.70 \pm 0.03$ & $0.88 \pm 0.04$ \\
7,12-Dioxo-lithocholic acid (10) & 3.85 & 2.36 & 3.0 & $0.58 \pm 0.01$ & $0.75 \pm 0.03$ \\
12 $\alpha$-Hydroxy-3,7-dioxo-cholanoic acid (11) & 3.52 & 1.99 & 3.0 & $0.55 \pm 0.02$ & $0.73 \pm 0.02$ \\
3,7,12-Trioxo-cholanoic acid (12) & 4.01 & 2.33 & 2.5 & $0.48 \pm 0.01$ & $0.65 \pm 0.02$ \\
Hyodeoxycholic acid (13) & 4.13 & 4.51 & 5.0 & $1.07 \pm 0.04$ & $1.23 \pm 0.05$ \\
\hline
\end{tabular}


(A)

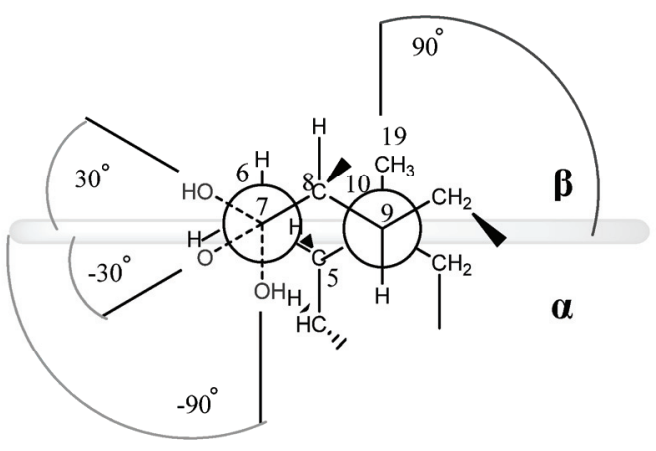

(B)

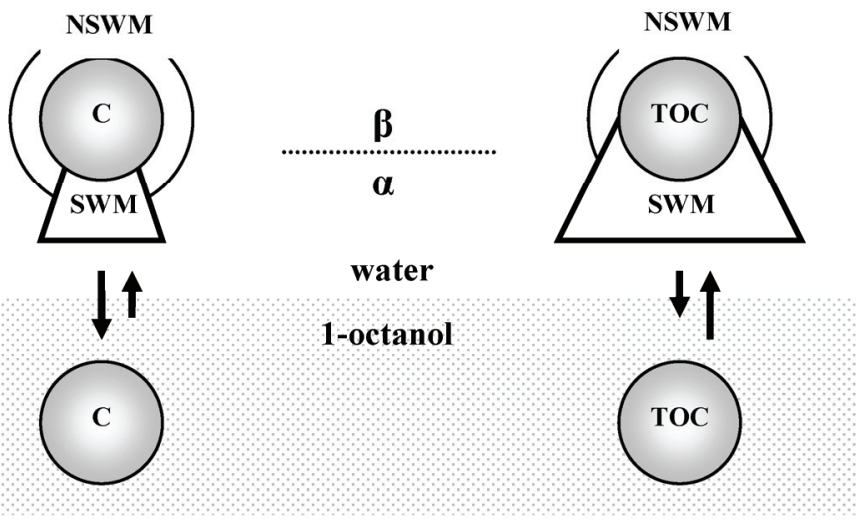

Figure 3. A) Change in the orientation of the oxygen atom with respect of mean plane of the steroid skeleton in the oxidation of the $\mathrm{OH}$ group to oxo group (Nevman's projection). B) Effect of the substitution of the OH group with oxo group on the distribution of bile acids between the organic and aqueous phases (SWM hydrogen-bond stabilized water molecules; NSWM water molecules not stabilized by hydrogen bonds; C: cholic acid; TOC: 3,7,12-trioxocholanoic acid).

it binds to the polar stationary phase (polar groups of the stationary phase stand for the SWM), that is it remains a shorter time in the mobile phase, which gives a higher $R_{\mathrm{M}}$ value (shorter $R_{\mathrm{f}}$ value) and a higher intercept $\left(R_{\mathrm{M}}{ }^{0}\right)$.

In view of the above discussion concerning the importance of the steric orientation of the oxygen atom (either in the $\mathrm{OH}$ or oxo groups bound to the steroid skeleton) in the determination of the lipophilicity of bile acids a new descriptor (ND) is introduced here which takes also into account the conformational characteristics as well as the distances in the corresponding molecular graph, i.e., it possesses both 2D and 3D topological characteristics $[14,15]$. This descriptor is calculated by the following formula:

$N D=\frac{\frac{1}{n} \sum \angle_{\mathrm{o}, \mathrm{am}}}{\sum d_{\mathrm{o}, \mathrm{o}}+\sum d_{\mathrm{o}, \mathrm{ph}}}$

where $n$ is the number of $C$ atoms in the steroid skeleton with the $\mathrm{OH}$ or oxo groups bonded to it; $\angle_{\mathrm{O}, \mathrm{am}}$ represents the angle between the $\beta$-axial $(a)$ angular methyl group and $\mathrm{OH}$ or oxo group in the corresponding Newman projection formula $\left(\angle_{\mathrm{O}, \mathrm{am}}: \alpha(a) \mathrm{OH}=180^{\circ}\right.$; $\alpha$ (equatorial, $e) \mathrm{OH}$ or oxo $=120^{\circ} ; \beta(e) \mathrm{OH}$ or oxo $=$ $\left.=60^{\circ}\right) ; d_{0,0}$ represents the mutual distance between the $\mathrm{C}$ atom to which the $\mathrm{OH}$ or oxo groups of the steroid skeleton (in the units of single bonds) are bonded, whereas $d_{0, p h}$ is the distance between the $C$ atom with $\mathrm{OH}$ or oxo groups from the steroid skeleton and polar head from the side chain (in the units of single bonds, the shortest path in the graph of the bile acid molecule). As can be seen from Table 1, the values of $N D$ in the congeneric groups of bile acid with two and three oxygen atoms in the steroid skeleton decrease when the $\mathrm{OH}$ group is replaced with an oxo group. Between the retention constants, $R_{\mathrm{M}}{ }^{0}$, and the descroptor $N D$ there exists a good correlation (Pearson's correlation, Table 2). This indicates that the chromatographic quantity $\left(R_{\mathrm{M}}{ }^{0}\right)$ for both solvent systems describes appropriately structural properties of bile acids. This is also evident from Figure $4 \mathrm{~A}$, where bile acids are represented in the plane: $R_{\mathrm{M}}{ }^{0}$ :toluene-ethanol and $R_{\mathrm{M}}{ }^{0}$ :toluene-butanol. Namely, the investigated bile acids are grouped in the plane $R_{\mathrm{M}}{ }^{0}$ in accordance with their structural characteristics: dihydroxy $(\mathbf{1}, \mathbf{2})$ bile acids; bile acids with one $\mathrm{OH}$ group and one oxo group $(7,5)$ as well as chiodeoxycholic acid (13) which, although being a dihydroxy derivative, its $\mathrm{C} 6 \mathrm{OH}$ group is of the equatorial orientation, i.e., it makes an angle of $60^{\circ}$ with the 


\begin{tabular}{|c|c|c|c|c|c|}
\hline & $\log P$ & $C \log P$ & $N D$ & $R_{\mathrm{M}}{ }^{0}$ Toluene/ethanol & $R_{\mathrm{M}}{ }^{0}$ Toluene/butanol \\
\hline $\log P$ & 1 & $0.745^{a}$ & 0.345 & 0.403 & 0.401 \\
\hline$C \log P$ & & 1 & $0.830^{a}$ & $0.876^{a}$ & $0.862^{a}$ \\
\hline$N D$ & & & 1 & $0.984^{a}$ & $0.991^{a}$ \\
\hline$R_{\mathrm{M}}{ }^{0}$ toluene/ethanol & & & & 1 & $0.997^{a}$ \\
\hline$R_{\mathrm{M}}{ }^{0}$ toluene/butanol & & & & & 1 \\
\hline
\end{tabular}

(A)

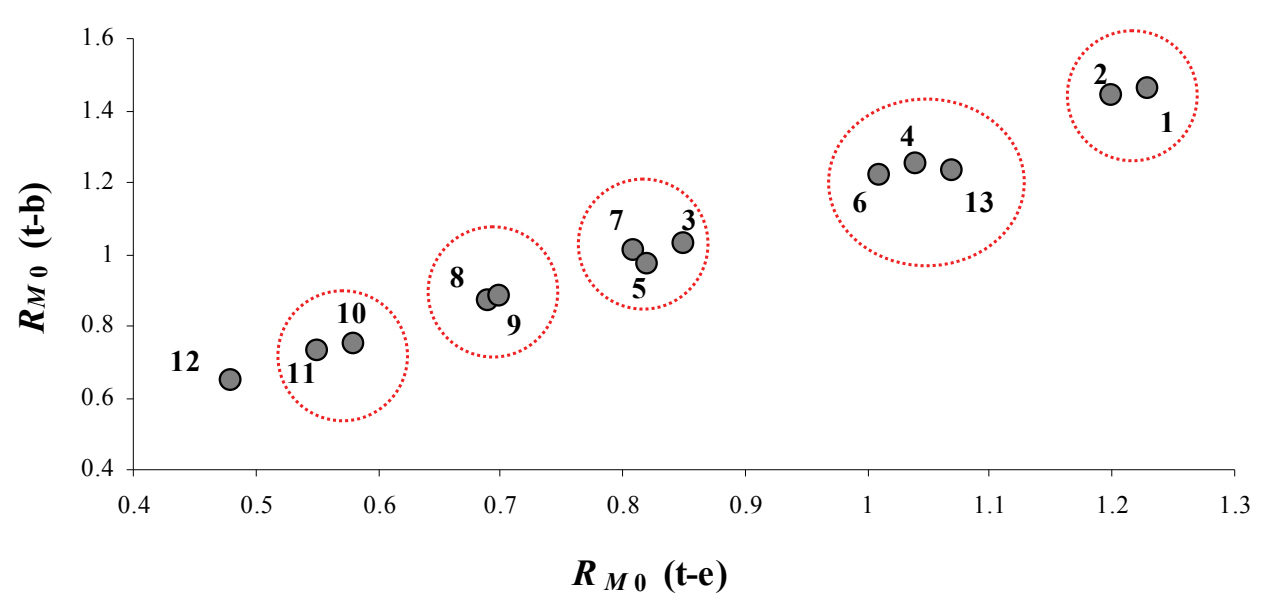

(B)

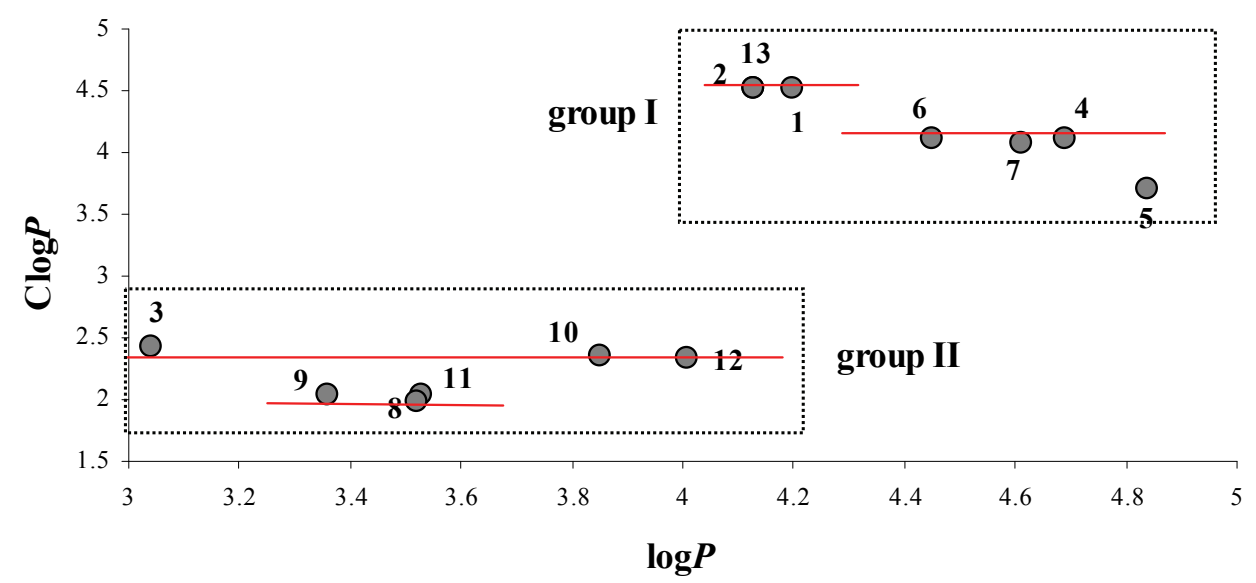

Figure 4. Pattern recognition A) in the plane of the experimentally determined NP TLC $R_{M}{ }^{0}$ parameters (t-e toluene-ethanol; $t-b$ toluene-butanol) and $B$ ) in the plane of the in silico lipophilicity descriptors.

mean plane of the steroid skeleton (Newman's projection), as well as the oxygens of the oxo groups $(7,5)$; bile acids with two oxo groups $(\mathbf{7}, 5)$ and cholic acid $(3)$; bile acids with two $\mathrm{OH}$ groups and one oxo group $(\mathbf{8 , 9})$; bile acids with two oxo groups and one $\mathrm{OH}$ group $(\mathbf{1 0 , 1 1 )}$, and bile acid with three oxo groups (12). If the grouping of bile acids is considered based on their in silico log $P$ (atomic-based prediction) and Clog $P$ (fragment-based prediction) values (Table 1 and Figure 4B), it can be noticed that there is no continuous change like that shown in Figure 4A, but characteristic congeneric groups are formed (group I: bile acids with two oxygen atoms and group II: bile acids with three oxygen atoms). Within the congeneric group II, cholic acid (3) and dioxo (10) and trioxo (12) derivatives have identical $C \log P$ values, whereas the $\log P$ value is larger for dioxo and trioxo derivatives than for cholic acid; similar anomalies being also oberved in the congeneric group I. Between the in silico $\log P$ and $N D$ descriptors, that is between the retention constants, $R_{\mathrm{M}}{ }^{0}$, there does not exist a significant correlation (Table 2), whereas between the in silico $C \log P$ and $N D$, that is $R_{\mathrm{M}}{ }^{0}$, there exists a weak correlation (Table 2).

The reason why the in silico $\log P$ (atomic-based prediction) and $C \log P$ (fragment-based prediction) descriptors do not adequately describe the lipophilicity of 
bile acid oxo derivatives lies in the fact that these lipophilicity quantities are obtained based on the calibration molecules, which are fragmented, and applying the least squares fitting procedure with the extrapolation to the sought structure. However, if the calibration set does not contain a molecule with similar conformation (steric environment) as the sought molecule, then the predicted value may deviate from the real value $[11,13]$.

\section{CONCLUSIONS}

The NP TLC retention constants, $R_{\mathrm{M}}{ }^{0}$, determined for both solvent systems (toluene-ethanol and toluenebutanol), describe adequately the lipophilicity of hydroxy and oxo derivatives of bile acids. Good correlation between $R_{\mathrm{M}}{ }^{0}$ and $N D$ descriptor, which has both $2 \mathrm{D}$ and $3 \mathrm{D}$ topological characteristics, indicates that the parameter $R_{\mathrm{M}}{ }^{0}$ reflects the steric changes arising in the oxidation of the $\mathrm{OH}$ group of the steroid skeleton to oxo group. Hence, $R_{\mathrm{M}}{ }^{0}$ may be effectively used in the QSAR investigations of bile acids.

\section{Acknowledgement}

Authors acknowledge financial support of the Ministry of Science and Technological Development of the Republic of Serbia (Project No. 172021) and the Secretariat of Science and Technological Development, AP Vojvodina, Republic of Serbia (Grant no. 114-451-2113/ /2011).

\section{REFERENCES}

[1] M. Calabresi, P. Andreozzi, C. La Mesa, Supra-molecular association and polymorphic behaviour in systems containing bile acid salts, Molecules 12 (2007) 1731-1754.

[2] A. Roda, A.F. Hofmann, K.J. Mysels, The influence of bile salts structure on self-association in aqueous solution, $\mathrm{J}$. Biol. Chem. 258 (1983) 6362-6370.

[3] J.M. Armstrong, C.M. Carey, The hydrophobic-hydrophilic balance of bile salts. Inverse correlation between reverse-phase high performance liquid chromatographic mobilities and micellar cholesterol-solubilizing capacities, J. Lipid. Res. 23 (1982) 70-80.

[4] C. Thomas, R. Pellicciari, M. Pruzanski, J. Auwerx, K. Schoonjans, Targeting bile-acid signalling for metabolic diseases, Nature Rev. Drug Discov. 7 (2008) 678-693.

[5] M.A. Dopico, V.J. Walsh, J. Singer, Natural bile acids and synthetic analogues modulate large conductance $\mathrm{Ca}^{2+}$ -activated $\mathrm{K}^{+}\left(\mathrm{BK}_{\mathrm{Ca}}\right)$ channel activity in smooth muscle cells, J. Gen. Physiol. 119 (2002) 251-273.

[6] C.L. Bowe, L. Mokhtarzadeh, P. Venkatesen, S. Babu, H. Axelrod,. M.J. Sofia, R. Kakarla, T.Y. Chan, J.S. Kim, H.J. Lee, G.L. Amidon, L.Y. Choe, S. Walker, D. Kahne, Desing of compounds that increase the absorption of polar molecules, Proc. Natl. Acad. Sci. USA 94 (1997) 12218$-12223$.

[7] G.S. Gordon, A.C. Moses, R.D. Silver, J.R. Flier, M.C. Carey, Nasal absorption of insulin: enhancment by hydrophobic bile salts, Proc. Natl. Acad. Sci. USA 82 (1985) 7419-7423.
[8] M. Poša, K. Kuhajda, Hydrophobiciti and haemolytic potential of oxo derivatives of cholic, deoxycholic and chenodeoxycholic acids, Steroids 75(6) (2010) 424-431.

[9] N.U. Perišić-Janjić, S.O. Podunavac-Kuzmanović, RPTLC study of QSRR and QSAR for some benzimidazole derivatives, J. Planar Chromatogr. 21 (2008) 135-141.

[10] A. Pyka, M. Dolowy, Lipophilicity of selected bile acids as determined by TLC, J. Liq. Chromatogr. R. T. 26 (2003) 2741-2750.

[11] F.D. King, Medicinal Chemistry: Principles and Practice, R.S.C., Cambrigdge, 2002.

[12] C. Sârbu, K. Kuhajda, S. Kevrešan, Evaluation of the lipophilicity of bile acids and their derivatives by thin-layer chromatography and principal component analysis, J. Chromatogr., A 917 (2001) 361-366.

[13] W. Camile, The Practice of Medicinal Chemistry, Academic Press, Oxford, 2003.

[14] R. Todeschini, V. Consonni, Handbook of Molecular Descriptors, Wiley-VHC, Weinheim, 2000.

[15] M. Karelson, Molecular Descriptors in QSAR/QSPR, Wiley \& Sons Inc, New York, 2000.

[16] M. Poša, Z. Farkaš, Cholesterol solubilization by oxo derivatives of selected bile acids and their membranotoxicity, Collect. Czech. Chem. Commun. 75(8) (2010) 767-784.

[17] M. Poša, S. Kevrešan, M. Mikov, V. Ćirin-Novta, K. Kuhajda, Effect of cholic acid and its keto derivatives on the analgesic action of lidocaine and associated biochemical parametars in rats, Eur. J. Drug. Metab. Pharmacokinet. 32 (2007) 109-117.

[18] M. Poša, V. Guzsvány, J. Csanádi, S. Kevrešan, K. Kuhajda, Formation of hydrogen-bonded complexes between bile acids and lidocaine in the lidocaine transfer from an aqueous phase to chloroform, Eur. J. Pharm. Sci. 34 (2008) 281-292.

[19] M. Poša, K. Kuhajda, Influence of bile acids on the adsorption of lidocaine and verapamil in an in vitro experimrnt, J. Serb. Chem. Soc. 75(4) (2010) 433-440.

[20] D. Miljković, K. Kuhajda, J. Hranisavljević, Selective C-12 oxidation of cholic acid, J. Chem. Res. (Synopsis) (1996) 106-107.

[21] B.F. Tullar, Hemi-diethylene glycol adduct of 3,12-dihydroxy-7-ketocholanic acid and preparation thereof. U.S. Patent 2,549,947, 1951.

[22] S. Kuwada, S. Furushiro, M. Kawashima, Partial oxidation of methyl cholate, An. Rep. Takeda Res. Lab. 8 (1949) 50-61.

[23] L.F. Fieser, S. Rajagopalan, Oxidation of Steroids III. Selective oxidations and acylations in bile acid series, J. Am. Chem. Soc. 72 (1950) 5530-5536.

[24] L.R. Snyder, J.J. Kirkland, Introduction to Modern Liquid Chromatography, Wiley-Intersciens, New York, 1979.

[25] M. Poša, S. Kevrešan, M. Mikov, V. Ćirin-Novta, K. Kuhajda, Critical micellar concentrations of keto derivatives of selected bile acids: Thermodynamic functions of micelle formation, Colloid. Surf., B 64 (2008) 151-161.

[26] M. Poša, A. Pilipović, M. Lalić, The influence of $\mathrm{NaCl}$ on hydrophobicity of selected, pharmacologically active bile acids expressed with chromatographic retention index and critical micellar concentration, Colloid. Surf., B 81 (2010) 336-343. 


\section{IZVOD}

\section{PRILOG ISPITIVANJU HIDROFOBNOSTI (LIPOFILNOSTI) ŽUČNIH KISELINA, SA OSVRTOM NA OKSO DERIVATE $5 \beta$-HOLANSKE KISELINE}

Mihalj Poša ${ }^{1}$, Milena Rašeta ${ }^{2}$, Ksenija Kuhajda ${ }^{2}$

${ }^{1}$ Departman za farmaciju, Medicinski fakultet, Univerzitet u Novom Sadu, Novi Sad, Srbija

${ }^{2}$ Departman za hemiju,Prirodno-matematički fakultet, Univerzitet u Novom Sadu, Novi Sad, Srbija

(Naučni rad)

Okso derivati žučnih kiselina u poslednjih 15 godina imaju sve veću primenu u biofarmaciji. Naime, nađeno je da imaju promotorna delovanja na transport određenih lekova kroz različite membrane (lipofilne barijere). Takođe, okso derivati žučnih kiselina imaju i manju membranolitičku (toksičnu) aktivnost nego njihovi hidroksi analozi. Stoga je bitno nalaženje deskriptora koji adekvatno opisuju strukturu žučnih kiselina te se mogu koristiti u nalaženju kvantitativne zavisnosti između strukture i biološke aktivnosti tj. u QSAR modelovanju. Stoga se u ovom radu ispituje primena retencione konstante RMO, dobijenog pomoću tankoslojne hromatografije na normalnim fazama (NP TLC) u sistemima rastvarača toluen-etanol $i$ toluen-butanol (silikagel stacionarna faza), u opisivanju lipofilnosti žučnih kiselina. Takođe, u radu je uveden (konstruisan) i nov molekulski deskriptor (ND) koji ima 2D i 3D topološke karakteristike molekula. Između retencione konstante $R_{\mathrm{M}}{ }^{0} \mathrm{i}$ deskriptora ND postoji dobra korelacija, kako RMO tako i ND adekvatno opisuju strukturne (konformacione) promene koji se javljaju pri oksidaciji $\mathrm{OH}$ grupe steroidnog skeleta u okso grupu. Dok in silico deskriptori lipofilnosti, log $P$ (atomic based prediction) i Clog $P$ (fragment based prediction) kod okso derivata žučnih kiselina hidrofobnost predviđaju sa određenom greškom.
Ključne reči: Okso derivati žučnih kiselina - Hidrofobnost (lipofilnost) $\bullet R_{M}{ }^{0}-$ Retenciona konstanta 